\title{
SPECIATION OF HEAVY METALS IN THE SIDMENTS OF GUBI DAM, BAUCHI STATE, NIGERIA
}

\section{B. M. WUFEM, A. Q. IBRAHIM, N. S. GIN, M.A. MOHAMMED, E.O. EKANEM AND M.A. SHIBDAWA}

(Received 9 June, 2009; Revision Accepted 5 July, 2007)

\begin{abstract}
Speciation of heavy metals in the sediments of Gubi Dam in Bauchi, Nigeria was carried out between December, 2001 and March, 2002. The mean total concentrations showed that Tatimari tributary has high $\mathrm{Fe}, \mathrm{Zn}$, and $\mathrm{Mn}$, confirming it source and path. The spillway result suggest intensive farming activity along the dam runway. However, the physio-chemical forms of $\mathrm{Fe}, \mathrm{Pb}$, and $\mathrm{Cr}$ indicate that these metals are associated in high concentration with the mineral matrix of the sediment, as such it is most unlikely to become biologically available. High levels of $\mathrm{Cu}, \mathrm{Cd}, \mathrm{Zn}, \mathrm{Mn}$, Co and $\mathrm{Ni}$ are associated with the exchangeable carbonate bound fractions, indicating that they are in potentially available forms and many pose serious problems to the dam ecosystem.
\end{abstract}

KEY WORDS: Sediments, Speciation, Heavy metals, Gubi Dam, Nigeria

\section{INTRODUCTION}

Many drainage basins serve as sinks for metal contaminants and as a result there has been increasing concern about the levels of toxic metals in aquatic systems. Water quality studies have always focused on point source pollution with much attention being paid to dissolved contaminants (Sinclair et al., 1989). However, the sediments and suspended load can be more significant in transportation of contaminants and nutrients than the dissolved load (Shear and Watson, 1977; Cullen et al., 1979; Allen 1986). The fact that large quantities of contaminants are transported in association with sediment suggest that problems may arise where contaminants are biologically available or can become biologically available.

The biological or chemical forms of species may affect all aspects of the metal behaviour and biological effects for different natural water systems which contain different proportion of the various species (Charles, 1989). The behaviour of these forms and species is governed by speciation, which influences heavy metal bioavailability and toxicity to biota, its transportation and mobilization and its interaction with the sediments and soil (Patrick, 1987). However, monitoring water quality using sediment has been associated with problems of heterogeneity (Abubakar and Ayodele, 2002). Nevertheless, adsorption of heavy metals by clay and organic fractions suggests that sediments can be used as pollution indicators. The heavy metal loads in water, suspended materials and sediments for rivers have been reported (Sinclair et al., 1989; Sarmani, 1989). The metal accumulation in trace sediments and in shells of mollusks have been reported for Tiga Lake in Kano, Nigeria (Abubakar and Ayodele, 2002).

B.M. Wufem, Chemistry Programme, Abubakar Tafawa Balewa University, P.M.B. 0248, Bauchi

A.Q. Ibrahim, Environmental Management Technology Programme Abubakar Tafawa Balewa University, P.M.B. 0248, Bauchi

N.S. Gin, Environmental Management Technology Programme Abubakar Tafawa Balewa University, P.M.B. 0248, Bauchi

M. A. Mohammed,

E. O. Ekanem,

M. A. Shibdawa, Chemistry Programme, Abubakar Tafawa Balewa University, P.M.B. 0248, Bauchi 
Birch et al., (2001) reported that heavy metals content of stream-bed sediments characterized environmental impacts in rural catchments and serve as sources of contamination. The sediments in a creek flowing through a country town was found to be enriched in $\mathrm{Cr}, \mathrm{Pb}$, and $\mathrm{Zn}$ over background concentrations.

Heavy metal-bearing sediments enter river systems by discharging of mine or processing waste, tailing dam failures, remobilization of mining areas and mine drainage (Hudson-Edwards, 2003). Lin et al., (2003) studied the mobility and toxicity of metals associated with sediments in Ke-ya and Ell-ren rivers in Taiwan. The result showed that the exchangeable, carbonate-bound and $\mathrm{Fe} / \mathrm{Mn}$ oxide-bound forms were considered to be mobile and related with anthropogenic pollution. The impacts of domestic and industrial waste on water and sediments have been reported to be higher in the rainy season due to runoff, from contaminated sites, agricultural fields and industries (Gaur et al., 2005). The heavy metal levels in sediments in the coast of South-West Iberian Peninsula predominates $60 \%$ in the $\mathrm{Fe}$ and $\mathrm{Zn}$ at industrial and non-industrial areas (Saenz et al., 2005). However, in some other industrial areas, Saenz et al., (2005) found less than $60 \% \mathrm{Cu}, \mathrm{Zn}$ and $\mathrm{Cd}$ in the residual fractions. The distribution of trace metals in sediments and water body have been reported to be influenced by season and flow conditions (Zhou et al., 2003; Cenci and Martin, 2004; Buck et al., 2005). In a study on three hard-water dams of Mooi River in South Africa, Van Aardt and Erdmann (2004) reported that the highest concentration of $\mathrm{Cd}$ and $\mathrm{Cu}$ were found in all the three dams, while highest lead was found in Potchfsroom dam.

Various methods have been used to assess the levels of meal contamination in sediments. The sequential chemical extraction schemes for heavy metals (Tessier et al., 1979; Sarmolloff et al., 1983; Kernsten and Forstner, 1987 ) and the chemical extraction and algae assay schemes for nutrient (Williams et al., 1980; Young and Depinto, 1982; Ellis and Standford, 1988) have been used for sediment-bound heavy metals in aquatic systems and soils. Trace metals in water and sediment was also studied using inductively couple plasma atomic emission spectrophotometer (ICP-AES) (Singh et al., 2005). This work therefore, determines the various forms and distribution of heavy metals in the exchangeable fractions of the sediments from Gubi dam. It is expected that the result obtained would provide the level of contamination and the likely effect on the water quality of the dam.

\section{EXPERIMENTAL Study Area}

Gubi dam was constructed in 1979 to serve as a permanent water supply scheme for irrigation and dairy farming to Bauchi and its environs. It has a top water level of $577 \mathrm{M}$ and 3KM long. Tatimari (Shadawanka and Dinya), Suntum, Kumi and Larkarina provide the major tributaries to the dam. It is located in northern part of Bauchi, Nigeria (Fig 1). The dam lies within the boundary of longtitude $10^{\circ} 25^{\prime} \mathrm{N}$ to $10^{0} 26^{\prime} \mathrm{N}$ and latituide $9^{0} 51^{\prime} \mathrm{E}$ to $9^{0} 52^{\prime} \mathrm{E}$. The region is classified as tropical, and the annual rainfall in the dam basin ranges from $970 \mathrm{~mm}$ to $1400 \mathrm{~mm}$ with about 50 to $60 \%$ of this rainfall occurring between July and August. Fishing, recreation, irrigation, dairy farming and water treatment take place around the dam (BASWAB, 1990).

\section{Samples Collection and Preparation}

Sediment samples were collected during an extensive environmental and aquatic pollution survey of Gubi dam. Samples were taken on two (2) occasions: high flow (September, 2001) and low flow (January, 2002) at the main entries (tributaries) of the dam and outlet (spillway) locations.

Sediment samples approximately 5 to $10 \mathrm{~cm}$ depth were taken from both sides of the tributes and the spillway using a plastic scoop. The samples were stored in an acid washed, wide-mouthed, plastic bottles. It was air-dried for seven (7) days and then ground to find particles using a ceramic mortar and pestle. The ground samples were then sieve with a $2.00 \mathrm{~mm}$ mesh (No.18) silk sieve to remove rubble or other dirty materials.

\section{Analytical Methods \\ Determination of total metal concentration}

$0.5 \mathrm{~g}$ of prepared sediment sample was weighed and transferred into a $500 \mathrm{ml}$ round bottom flask wetted with a few drops of deionized distilled water, $1 \mathrm{oml}$ of aquaregia was measured and transferred into the $500 \mathrm{ml}$ round bottom flaks containing sediment and the mixture was heated in a fume cupboard at low heat $\left(120^{\circ} \mathrm{C}\right)$ for one hour. The temperature was then increased to produce white dense fumes and mixture evaporated to approximately $0.5 \mathrm{ml}$. The mixture was further digested with $1 \mathrm{ml}$ of percloric acid $\left(\mathrm{HClO}_{4}\right)$ and evaporated to dryness. The residue was dissolve with $20 \mathrm{~cm}^{3}$ of $1 \%(\mathrm{v} / \mathrm{v})$ nitric acid, 
and transferred to $100 \mathrm{ml}$ volumetric flask. It was made up to the mark with dilute nitric acid $91 \%$ $(\mathrm{v} / \mathrm{v})$. The heavy metal concentrations in the digest were determined a Buck Scientific Model GP 210 using Atomic Absorption Spectrophotometer (AAS).

\section{Metal Speciation}

The method developed by Tessier et al., (1979) and Stone and Droppo (1996) were used to determined the physico-chemistry for each metal in the sediment as follows:

Exchangeable Metal- $1 \mathrm{~g}$ of sediment samples was weighed and transferred into $250 \mathrm{ml}$ conical flask. The sample was extracted with $10 \mathrm{ml}$ of $1 \mathrm{M}$ $\mathrm{NaOAC}$, adjusted to $\mathrm{pH} 8.2$ with acetic acid and shaken for 2 hours using a mechanical shaker. It was filtered using Whatman No. 1 and the filtrate analyzed for metals.

Carbonate Bound Metals- the residue from exchangeable metal was leached three successive times with $10 \mathrm{ml} \mathrm{NaOAC}$ adjusted to $\mathrm{pH} 5.0$ with acetic acid and shaken for 30 minutes. This was also filtered using Whatman No.1 and the filtrate analyzed.

Mn-oxide bound metals- the residue from carbonate bound metal was leached with $10 \mathrm{ml}$ $0.1 \mathrm{M} \mathrm{NH}_{2} \mathrm{OH}, 0.01 \mathrm{M} \mathrm{HNO}_{3}$ adjusted to $\mathrm{pH} 2.0$ with acetic acid and shaken for 3 hours. It was filtered using Whatman No.1.

Fe-Mn oxide metals-the residue from Mn-oxide bound metals extract was extracted with $10 \mathrm{ml}$ oxalate buffer [90.02M $\left(\mathrm{NH}_{4}\right)_{2} \mathrm{C}_{2} \mathrm{O}_{4}, 0.02 \mathrm{M} \mathrm{H}_{2} \mathrm{C}_{2}$ $\mathrm{O}_{4} \mathrm{pH}_{3}$ ] and was shaken for 12 hours at $90^{\circ} \mathrm{C}$ in a water bath. This was filtered using Whatman No. 1.

Organic matter and sulfides bound metalsthe residue from $\mathrm{Fe}-\mathrm{Mn}$ oxide bound metals extract was extracted with $10 \mathrm{ml} \quad 30 \% \quad \mathrm{H}_{2} \mathrm{O}_{2}$ adjusted to $\mathrm{pH} 2.0$ with $\mathrm{HNO}_{3}$ and then extracted with $1 \mathrm{M} \mathrm{NH} \mathrm{NH}_{4} \mathrm{OAC}$ adjusted to $\mathrm{pH} 2.0$ with $\mathrm{HNO}_{3}$ at room temperature. The metals in the filtrate were determined.

Residual metal-the residue from organic matter and sulfides bound metals extract was digested with $10 \mathrm{ml}$ aqua-regia $(3: 1 \mathrm{HCl}$ : $\mathrm{HNO} 3)$.

Metal in fractions were determined using Buck Scientific Model GP210 Atomic Absorption Spectrophometer (AAS) GP210.

\section{RESULTS AND DISCUSSION}

The results of the total metal concentrations in Gubi dam sediments are shown in Figure 2. The result indicates that Tatimari site has the highest concentrations of $\mathrm{Fe}\left(2.26 \mathrm{mgL}^{-1}\right)$,
$\mathrm{Zn}\left(0.53 \mathrm{mgL}^{-1}\right)$ and $\mathrm{Mn}\left(0.50 \mathrm{mgL}^{-1}\right)$. These concentrations could be as a result of sewage and other discharges of waste from the city which agreed with the work of Costal et al., (1991). The spillway is intensively farmed, thus justifying the relatively high concentration of $\mathrm{Cr}$ and $\mathrm{Cd}$. This may be as a result of excessive washing away of inorganic fertilizer and herbicides by rain into the dam. The result of speciation of chemical fractions of heavy metals in Gubi dam sediments is shown in Table 1. The higher concentrations of iron and zinc and the low concentrations of chromium and nickel in most of the sediments show the changes in the metal content of the sediments with distance, thus suggesting that changes in the environment of deposition do occur along the dam. Consequently, this would result in metal accumulation in the sediment indicating the existence of localized metal pollution that is above the permissible concentration level recommended by the World Health Organization (WHO, 1984). These metals can be release by various processes of remobilization which give rise to the various forms of the metals in water, suspended matter and sediment.

The assessment of the extent of pollution in the dam may require the knowledge of the concentration of the various metal species in sediments. For representation of the dam, sediments at the tributaries, entry to the dam, and spillway were analyzed. The chemical forms of the heavy metals indicate the extent of their bioavailability and toxicity (Hart, 1982; Zhang, 1978). The higher the biologically active forms, the more polluted the water. The forms of each heavy metal in sediments taken from the dam (Fig.1) is shown in Table1. Highest percentages of $\mathrm{Cu}(31.42 \%)$ and $\mathrm{Cd}(62.39 \%)$ are associated with the exchangeable fractions while $\mathrm{Zn}$ $(24.73 \%), \mathrm{Mn}(32.73 \%)$, Co $(48.02 \%)$ and $\mathrm{Ni}$ $(32.92 \%)$ are associated with the carbonate fractions. These forms indicate that $\mathrm{Cu}, \mathrm{Cd}, \mathrm{Zn}$, $\mathrm{Mn}, \mathrm{Co}$ and $\mathrm{Ni}$ are in potentially available forms and may likely pose a serious problem to the ecosystem in the dam. This is because these fractions can be solubilized, and the metals become more available to broken in the dam. Despite the low levels of these metals (Fig.2), long residence time of the solubilized form can be threatening. The highest amount of $\mathrm{Fe}(23.71 \%)$ is associated with the organic and sulfide, and the mineral matrix of the sediment. Similarly, highest $\mathrm{Cu}(93.75 \%)$ is associated with the organic and sulfide $\mathrm{pb}(37.78 \%)$ is associated with the mineral matrix of the sediment. With the 

AND M. A. SHIBDAWA

$\mathrm{Fe}, \mathrm{Cr}$ and $\mathrm{Pb}$ primarily associated with the mineral matrix, it is most unlikely these forms would become biologically available.

\section{CONCLUSION}

Heavy metals in Gubi dam occur in low concentrations. However, $\mathrm{Cu}, \mathrm{Cd}, \mathrm{Zn}, \mathrm{Mn}, \mathrm{Co}$ and $\mathrm{Ni}$ are in biologically active forms and may be of threat to the ecosystem. Nevertheless, it does not suggest serious pollution. $\mathrm{Fe}, \mathrm{Cr}$ and $\mathrm{Pb}$ pose no threat to the living organisms in the water since they occur in non-potentially active forms. 


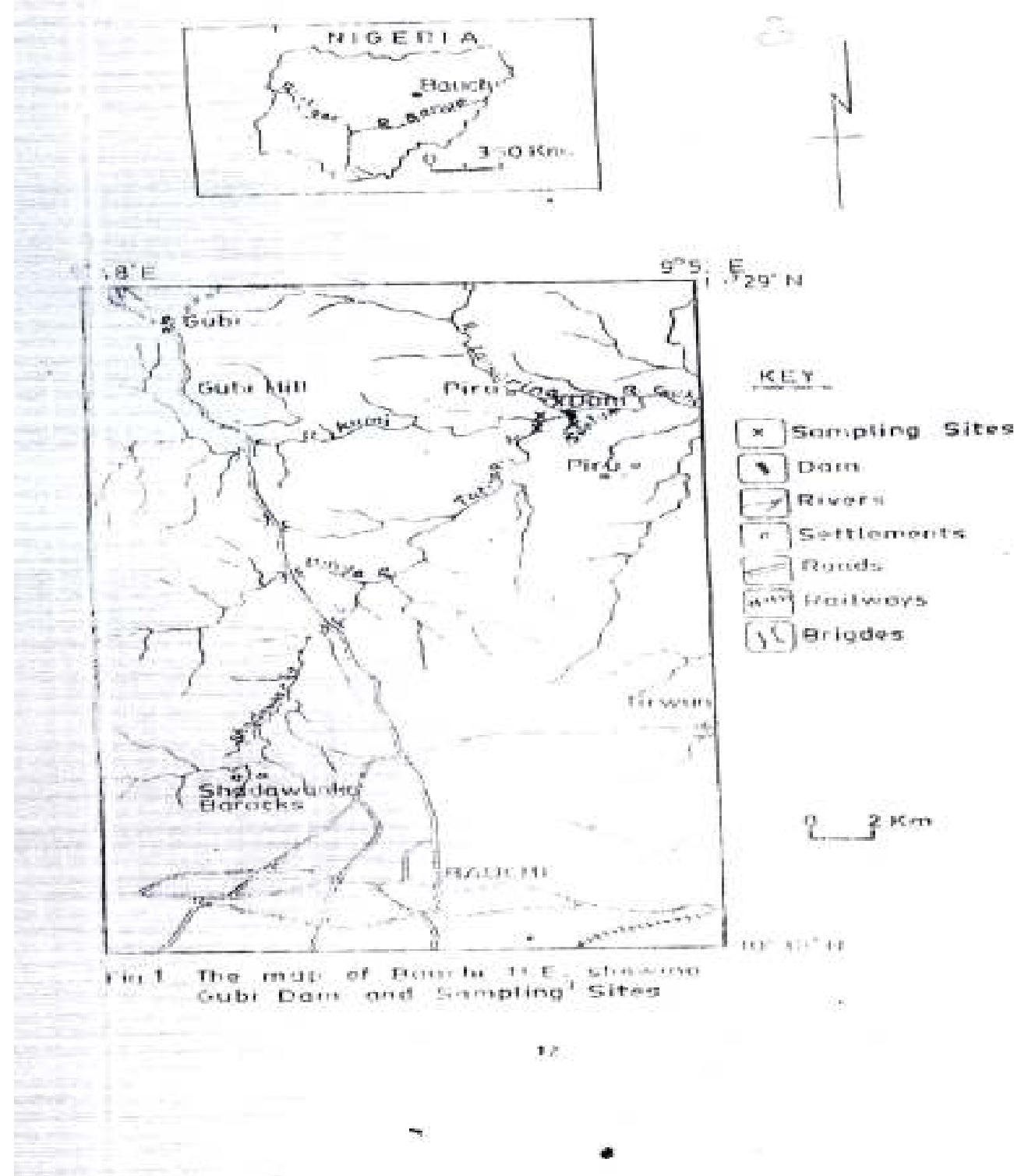




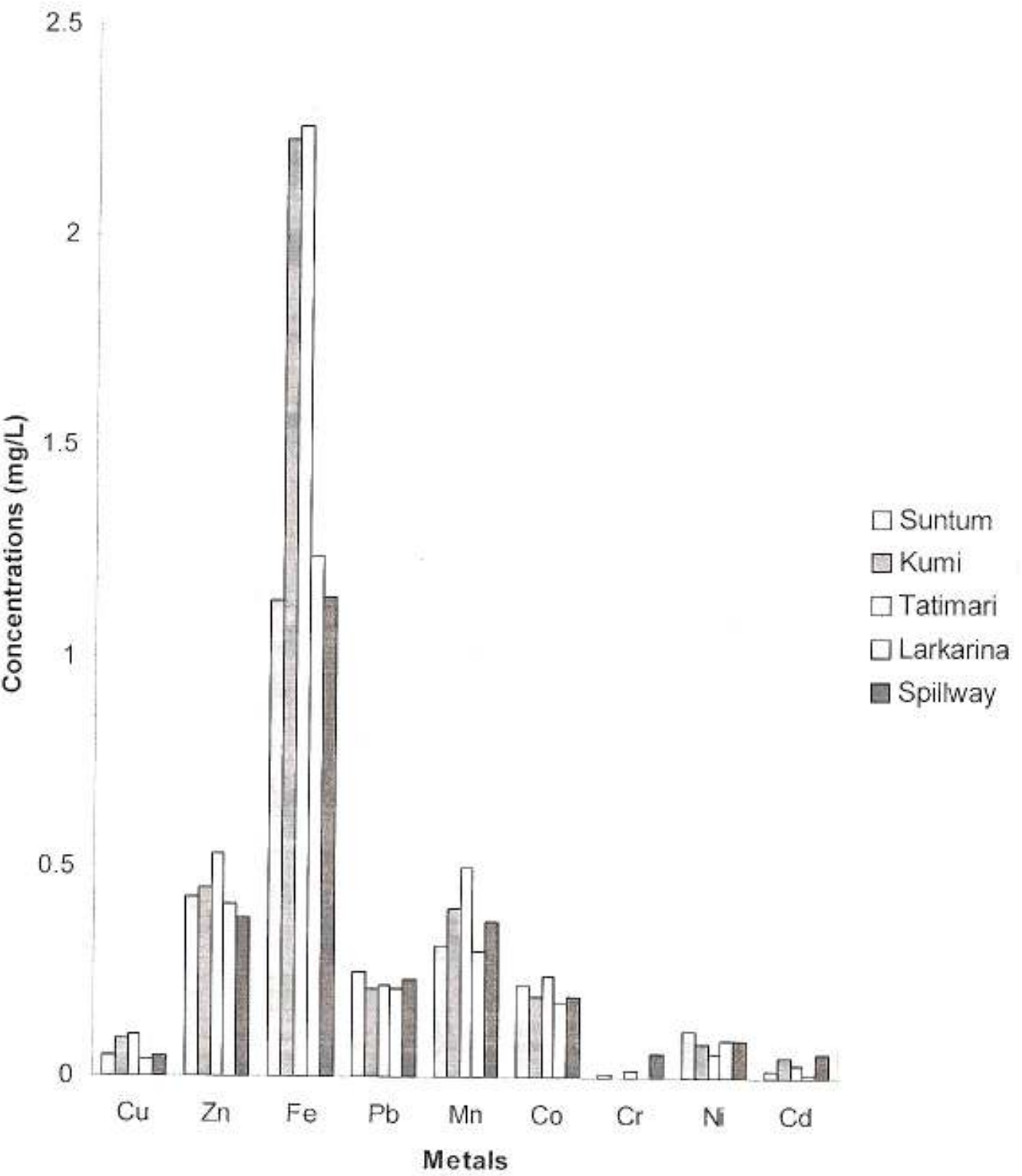

Fig.2 Mean Total Metal Concentrations (mg/L) 


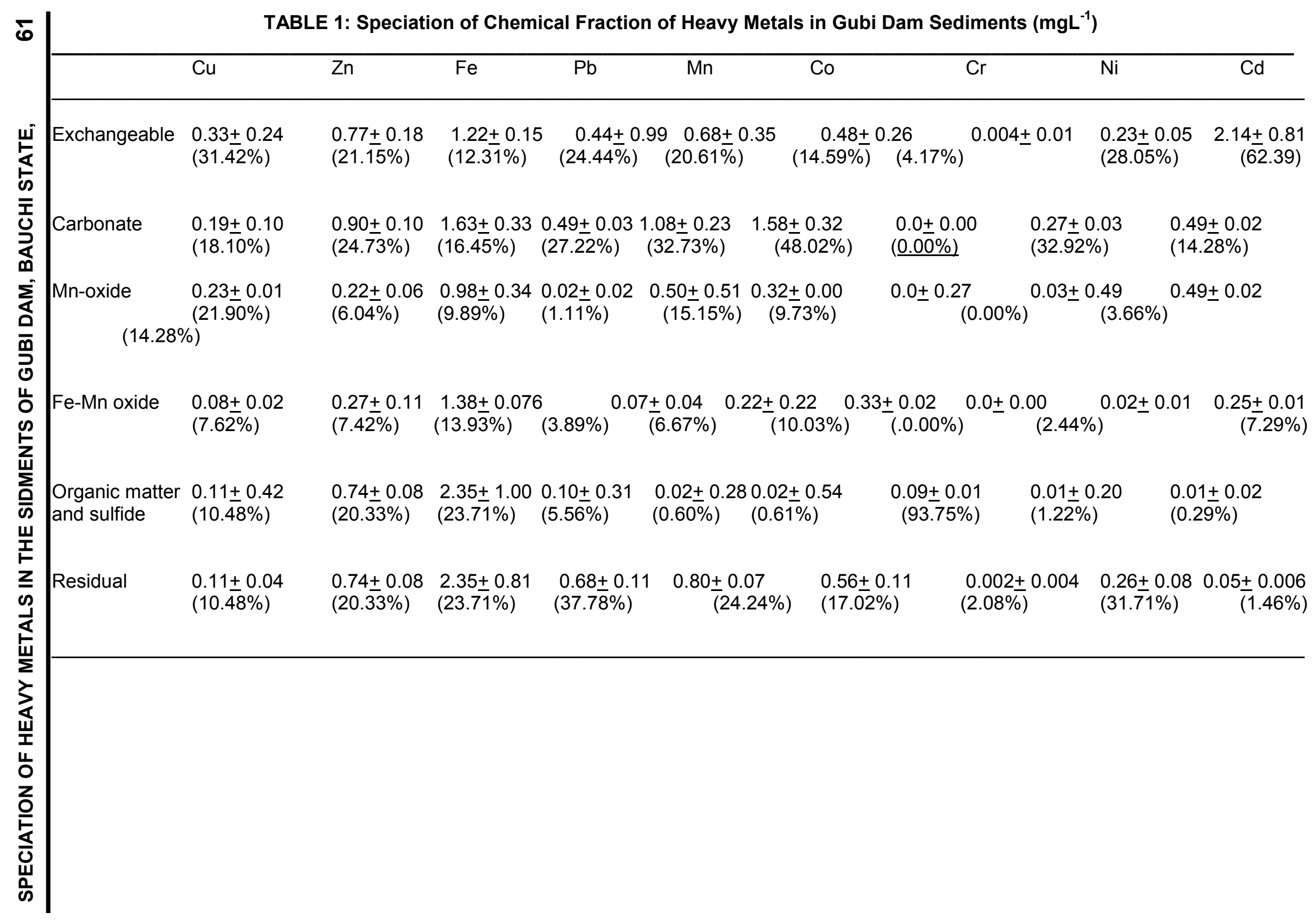




\section{REFERENCES}

Abubakar, M. and Ayodele, J.T., 2002. Meal accumulation in trace sediment and in the shells of two species of fresh-water mollusks in Tiga Lake, Kano, Nigeria. Nigerian Journal of Basic and Applied Sciences, 11,pp 81-90.

Allen, R.J., 1986. The role of particulate matter in the transport and burial of contaminants in aquatic ecosystems. In: Hart, B.T. (ed.) the role of particulate matter in the transport and fate of pollutants. Chisholm Institute of Technology, Melbourne, pp 196.

BASWB/TP/037, 1990. Bauchi State water Board Technical Paper "Decumentary of Gubi dam water supply scheme", Ramadan Printing Press, Bauchi, P4

Birch, G. Siaka, M. and Owns, C., 2001. The source of anthropogenic heavy metals in fluvial sediments of a rural catchments: Cox River, Australia. Water, Air and Soil Pollution 126(1-2): 13-35.

Buck, N.J., Gobler, C.J. and Sanudo-Wilhemy, S.A., 2005. Dissolved trace element concentrations in the East River-Long island Sound System: Relative importance of autochthonous versus allochthonous sources. Environ. Sci. Technol. 39(10): 3528-3537.

Cenci, R.M. and Martin, J.M., 2004. Concentration and fate of trace metals in Mekong river Delta. Sci. Total Environ. 332 (1-3): 167-182.

Charles, A.W., 1989. Hazardous waste management. McGraw-Hill Book Company, New York, $4^{\text {th }}$ edition, pp 9495.

Costal, M. Moveira, I. Sporkes, L. and Liss, P., 1991.Manganese species in surface waters from Guana Bara Bay, Riode-Jeneiro, Brazil. In: Proc. $3^{\text {rd }}$ Int. Environ. Chem. Congr. In Brazil.

Cullen, P., Rosich, R.S. and Bek, P., 1979. A phosphorous budget for Lake Burley Griffin and management implications for urban lakes. Aust. Water Resources
Council Tech. Paper, 31 Aust. Govt. Publishing Service Canberra.

Ellias, B.K. and Stanford, J.A., 1988. Phosphorous bioavailability of fluvial sediments determined by algal assays. Hydrobiologia, 160, pp. 9-18

Gaur, V.K., Gupta, S.K. Pandey, S.D., Gopal, K. and Misra, V., 2005. Distribution of heavy metals in sediments and water of river Gomti. Environ. Monit. Assess. 102 (1-3): 419533.

Hart, B.T., 1982. Uptake of trace metals by sediments and suspended particulates; a review. Hydrobiologia, 91, pp. 299-313.

Hudson-Edwards, K.A., 2003. Sources, mineralogy, chemistry and fate of heavy metals bearing particles in mining affected river systems. Mineralogy Magazine 67 (2): 205-217.

Kernsten, M. and Forstner, U., 1987. Effects of sample pretreatment on the reliability of solid speciation data for heavy metals: implications for the study of early diagenetic processes. Mar. Chem., 22, pp. 299-312.

Lin, J.G., Chen, S.Y. and Su, C.R., 2003. Assessment of sediment toxicity by metal speciation in different particle-size fractions of river sediments. Water, Sci. Technol. 47 (7-8): 233-241.

Patrick, B., 1987. Metal transfer across the airsea interface: myths and mysteries. In: Lead, Mercury, Cadmium and Arsenic in the environment (ed.) by Hutchinson, T.C. and Meema, K.M., Published by John Wiley and Sons Ltd., pp 148-308.

Saenz, V., Blasco, J. and Gomez-Parra, A., 2005. Speciation of heavy metals in recent sediment of three costal ecosystems in the Gulf of Cadiz, South-West Iberian Peninsula. Society Environmental Toxicology and Chemistry Online Journal 22 (12): 2833-2839.

Sarmani, S.B., 1989. The determination of heavy metals in water, suspended materials and sediment from Langat River, 
Malaysia. Hydrobiogia, 176/77, pp 233238,

Sarmolloff, M. R., Bell, J., Birkholz, D.A., Webstre, G.R.B., Arott, E.G., Pulak, P. and Modrid, A., 1983. Combined bioassay-chemical fractionation scheme for the determination and ranking of toxic chemicals in sediments. Envir. Sci. Technol., 17, pp 329-334.

Shear, H. and Watson, A.E.P., 1977. The fluvial transport of sediment associated nutrients and contaminants. International Joint Commission, Canada.

Sinclair, P., Beckett, R., and Hart B.T., 1989. Interaction between sediments and fresh water. Kluwer Academic Publishers, London, p 239.

Singh, V.K. Singh, K.P. and Mohan, D., 2005. Status of heavy metals in water and bed sediments of river Gomti-a tributary of the Ganga river, India. Environ. Monit. Assess. 105 (1-3): 43-67.

Stone, M and Droppo, I. G., 1996. Distribution of $\mathrm{Pb}, \mathrm{Cu}$ and $\mathrm{Zn}$ in size fractionated river bed sediment in two agricultural catchments of Southern Ontario, Canada. Environ. Poll., 93 (3): pp. 353362.

Tessier, A., Campbell, P .G.C. and Bisson, M., 1979. Sequential extraction procedure for the speciation of particulate trace metals. Analyt. Chem., 51, pp. 844-851.
Van Aardt, W.J. and Erdmann, R., 2004. Heavy metals $(\mathrm{Cd}, \mathrm{Pb}, \mathrm{Cu}, \mathrm{Zn})$ in mudfish and sediment from three hard-water dams of the Mooi River Catchments, South Africa. Water SA 30 (2): 211-218.

WHO, 1984. World Health Organization Guidelines for Drinking Water Quality. World Water, WHO, Geneva, Switzerland.

Williams, J.D.H. Shear, H. and Thomas, R. L., 1980. Availability of Schenedusmus quadricauda of different forms of $P$ in sedimentary materials from the Great Lake of Limnol. Oceanogr., 25, pp.1-111.

Young, T. C. and Depinto, J. V., 1982. Algal availability of particulate phosphorous from diffuse and point sources in the lower Great Lakes Basins. Hydrobiologia., 91,pp. 111-119.

Zhang, S., 1978. Toxic elements in the sediments of water bodies in China's semi-arid area and their environmental behaviour. In: Boxer, B. and Pramer, D. (eds.). Environmental Protection in the People's Republic of China, State University of New Jersey, Rutgers, pp 47-65.

Zhou, J. L. Liu, Y.P. and Abraham, P.W., 2003. Trace metal behaviour in the Conway estuary, North Wales. Chemosphere 51 (5): 429-440. 